\title{
ANALISIS EKONOMI USAHA TANI ANGGOTA SIMPAN PINJAM KELOMPOK PEREMPUAN PROGAM NASIONAL PEMBERDAYAAN MASYARAKAT MANDIRI PERDESAAN DI KECAMATAN SELOREJO KABUPATEN BLITAR
}

\author{
Niza Kenyo Ganda Arum \\ Arfida BR \\ Program Studi Ilmu Ekonomi Studi Pembangunan \\ Fakultas Ekonomi dan Bisnis \\ Universitas Muhammadiyah Malang \\ Jl. Raya Tlogomas No. 246 Malang \\ E-mail: nizakenyo@gmail.com
}

\begin{abstract}
This study aimed to analyze the differences bothincomeand yieldin Farmer's SPP group before and after receiving PNPM-MPdcredit. Primary data obtained from 50 respondents which were selected by purposive sampling.This research was conducted by qualitative research design by means descriptive.Thedata selected fromincome and yield before and after receiving PNPM-MPdcredit. While the data were processed by using a different test analysis paired sample mean.Analyzes result indicated that there was a mean differential both income and outcome production on Farmer's SPP group before and after the PNPM-MPd received credit. Evenly, the outcome production is about 8,28 Kw before receiving the credit and it was about 10,12 Kw after receiving the credit. However, the income had indicated about $R p$ 3.043.000 before the PNPM-MPd received credit and the outcome had indicated about $R p 5.160 .000$ after receiving thecredit. From the yield, it showed a more superior in income. This affected by cost factor through the rise.
\end{abstract}

Keywords: PNPM-MPD, SPP, Framer Business, Selorejo District.

\begin{abstract}
Abstrak
Penelitian ini bertujuan untuk menganalisis perbedaan hasil produksi dan pendapatan usaha tani anggota SPP sebelum dan sesudah menerima kredit PNPMMPd. Berupa data primer diperoleh dari 50 responden yang dipilih secara purposive sampling. Penelitian ini menggunakan metode deskriptif kuantitatif. Data yang digunakan meliputi data hasil produksi dan pendapatan sebelum dan sesudah menerima kredit PNPM-MPd. Data diolah menggunakan alat analisis uji beda mean sample berpasangan.Hasil analisis menunjukan bahwa adanya perbedaan rata- rata hasil produksi dan pendapatan usaha tani anggota SPP sebelum dan sesudah menerima kredit PNPM-MPd. Rata-rata hasil produksi sebelum menerima kredit 8,28 $\mathrm{Kw}$ dan sesudah menerima kredit 10,12 Kw. Sedangkan pendapatan sebelum menerima kredit PNPM-MPd Rp 3.043.000 dan sesudah menerima kredit sebesar Rp 5.160.000. Perbedaan atau peningkatan pendapatan lebih besar dari hasil produksi. Hal itu ditunjang dari faktor harga yang mengalami kenaikan.
\end{abstract}

Kata Kunci : PNPM-MPd, SPP, Usaha Tani, Kecamatan Selorejo. 


\section{PENDAHULUAN}

\begin{tabular}{lrr}
\multicolumn{2}{c}{ ProgamNasional } & Pember- \\
dayaan & Masyarakat & Mandiri \\
Perdesaan & (PNPM-MPd) & adalah \\
sebuah progam dari pemerintah yang \\
berfokus
\end{tabular}
masyarakat didaerah perdesaan. Yang bertujuan secara umum untuk meningkatkan kesejahteraan dan penyediaan pekerjaan untuk masyarakat perdesaan yang tergolong miskin. Dan bertujuan khusus untuk mengikut sertakan masyarakat dalam pembangunan serta mengembangkan kapasitas pemerintah daerah (BAPPENAS, Evalusi PNPM 2013:27).

Progam pemberdayaan dimulai pada tahun 1998 Progam Perkembangan Kecamatan (PPK), Progam Penanggulangan Kemiskinan Perkotaan (P2KP), Progam Percepatan Pembangunan Daerah Tertinggal Khusus (P2DTK). Dan pada tahun 2007 resmi diluncurkan PNPM Mandiri (BAPPENAS, Evalusi PNPM 2013:26).

Pengelolan PNPM Mandiri Perdesaan dilakukan di Kecamatan. Yang dibentuk Unit Pengelola Kegiatan (UPK). UPK bertanggung jawab untuk fasilisator pengelola dana PNPM yang dialokasikan untuk pembangunan sarana dan prasarana, infrastruktur, pendidikan, kesehatan, UEP (Usaha Ekonomi Produktif) dan SPP (Simpan Pinjam Perempuan). Kegiatan UEP dan SPP dikelola sebagai dana bergulir yaitu memberikan pinjaman secara kelompok usaha berama ataupun kelompok simpan pinjam (Petunjuk Teknis Operasional PNPM Mandiri Perdesaan : 2007).

Berjalanya waktu pada tahun 2015 PNPM-MPd dibidang pembangunan dialihkan oleh era pemerintahan baru menjadi progam pendampingan desa. Pembangunan desa tidak lagi di bawah naungan PNPM tetapi dikelola sendiri oleh desa dengan pembentukan APBDes. Dalam UU Desa pasal 72 ditetapkan bahwa belanja desa diprioritaskan untuk memenuhi kebutuhan pembangunan yang disepakati dalam musyawarah desa dan sesuai dengan prioritas pemerintahan kabupaten atau kota, pemerintahan provinsi dan pemerintah pusat. Selanjutnya semua kebutuhan, pelayanan dasar, lingkungan dan kegiatan pember- 
dayaan masyarakat desa (Ishom, 2015:6).

Dana PNPM yang masih berlangsung di kecamatan adalah berupa dana bergulir. Pada tahun 2011 kecamatan Selorejo kabupaten Blitar mendapat penghargaan PNPM-MPd terbaik nasional. Dengan katagori pemberian pelaporan secara obyektif dan tertata. Kecamatan Selorejo jika dilihat merupakan kecamatan yang sedang berkembang dan memiliki pertumbuhan yang cukup stabil. Namun jika dibandingkan dengan kecamatan tetangga seperti Sumberpucung dan Kesamben dapat dikatakan cukup tertinggal (Media Informasi Warga Kecamatan Selorejo, 2016).

\section{Kecamatan}

Selorejo

mengalokasikan dana bergulir PNPM dalam kegiatan Simpan Pinjam Perempuan (SPP). SPP sendiri adalah suatu kegiatan yang membentuk kelompok-kelompok perempuan yang mana kelompok tersebut diberikan kredit untuk menjalankan usaha. Karena pinjaman ini ditujukan untuk masyarakat desa, maka bunga yang ditetapkan rendah yaitu $1,5 \%$. Selain itu syarat pengajuan kredit pun mudah, dengan kemudahan tersebut pemerintah mengharapkan perempuan bisa berpartisipasi. Serta memanfaat kan peluang untuk melakukan kegiatan produktif yang mana perempuan ikut membantu perekonomian keluarga dan pembangunan desa.

Partisipasi masyarakat di Kecamatan Selorejo dikatakan tergolong cukup tinggi untuk mengikuti kegiatan Simpan Pinjam Perempuan (SPP). Kecamatan Selorejo sendiri terdapat 10 Desa dengan jumlah 60 klompok yang terdiri dari 5-20 anggota. Menurut UPK Kecamatan Selorejo, pinjaman sebagian besar digunakan untuk usaha tani $25 \%$, usaha dagang $20 \%$, UMKM $20 \%$, jasa $20 \%$ dan perikanan $15 \%$ (Laporan UPK Kecamatan Selorejo, 2016).

Sektor perekonomian yang menonjol pada kecamatan Selorejo terletak pada sektor pertanian dan perkebunan. Hal ini didukung oleh lahan yang digunakan untuk bercocok tanam masih luas, area luas tanaman bahan pangan kecamatan Selorejo mencapai 3.612 Ha, luas tanaman sayuran seluas $92 \mathrm{Ha}$ dan luas area tanaman perkebunan 
sebesar 771.13 Ha. Jika dilihat dari distribusi luas pengunaan lahan menurut penggunaanya di kecamatan Selorejo terbagi menjadi bangunan, perkarangan dan hutan negara sebesar $30,30 \%$, hutan rakyat seluas $1,1 \%$, sawah seluas $19,19 \%$, tegal atau kebun seluas 32,329 \% dan lainya (tambang, kolam, emppang dan lainya) seluas $18,18 \%$. Hal ini dapat disimpulakan bahwa tegal atau kebun merupakan lahan yang terluas menurut penggunaanya (BPS Kecamatan Selorejo,2016:9). Berdasarkan latar belakang diatas dapat dirumuskan masalah yaitu apakah ada perbedaaan hasil produksidan pendapatan usaha tani anggota kelompok Simpan Pinjam Perempuan (SPP) sebelum dan sesudah menerima kredit PNPMMPd.

\section{Berdasarkan perumusan} masalah diatas, maka tujuan penelitian ini adalah untuk menganalisis ada perbedaaan hasil produksidan pendapatan usaha tani anggota kelompok Simpan Pinjam Perempuan (SPP) sebelum dan sesudah menerima kredit PNPMMPd.
Berdasarkan penelitian sebelumnya oleh Nurmanto (2011) terkait kredit PNPM meningkatkan produksi, penyerapan tenaga kerja dan pendapatan usaha SPP. Dijelaskan bahwa kredit PNPM mampu meningkatkan kesejahtearaan usaha penerima kredit. Yang dilihat dari jumlah produksi, tenaga kerja dan pendapatan yang di hasilkan sebelum dan sesudah menerima kredit PNPM. Didapatkan setelah menerima kredit PNPM jumlah produksi, tenaga kerja dan pendapatan mengalami peningkatan yang signifikan.

Menurut penelitian Lestarini (2013) dengan hasil adanya progam simpan pinjam yang pro rakyat Progam PNPM dapat meninngkatkan kesejahteraan rakyat didesa lanji kecamatan Patebon Kabupaten Kendal. Hasil analisis SPP PNPMMP ternyata mampu untuk memberdayakan masyarakat. Dan dari hasil kuantitatif menunjukan pengaruh yang positif antara kredit SPP PNPM-MP dengan pendapatan masyarakat.

Menurut Winarni (dalam Sulistyani, 2004:79) mengungkapkan bahwa inti dari pemberdayaan 
adalah meliputi tiga hal yaitu pengembangan (enabling), memperkuat potensi atau daya (empowering), terciptanya kemandirian.

Menurut Anwas (2013:115) peran perempuan terutama dikalangan keluarga miskin cenderung dimarginalkan. Perempuan masih identik dengan urusan “dapur, sumur dan kasur". Pekerjaan perempuan terbatas pada mengurus rumah tangga. Jika suami istri bekerjasama dalam mencari nafkah keluarga berarti menyatukan dua kekuatan.

Pada PNPM terdapat salah satu pemberdayaanya yang berupa Bantuan Langsung Masyarakat.Yaitu dana simultan keswadayaan yang diberikan kepada kelompokmasyarakat untuk membiayai sebagian kegiatan oleh masyarakat dalam rangka meningkatkan kesejahteraan. Kegiatan tersebut bisa berupa kegiatan usaha dalam kelompok Simpan Pinjam Perempuan (SPP) dan Usaha Ekonomi Produktif (UEP).

Menurut

Suhardjono

(2003:287) kredit modal kerja adalah fasilitas kredit yang digunakan untuk membiayai kebutuhan modal kerja perusahaan yang pada umumnya berjangka waktu pendek, maksimal satu tahun.

Sedangkan menurut Suhardjono (2003: 288) modal kerja sendiri adalah dana untuk menghasilkan pendapatan (income). Setiap dana yang dikerjakan atau digunakan adalah dimaksudkan untuk menghasilkan pendapatan.

Modal merupakan faktor utama dalam pertanian. Kekurangan modal bisa menyebabkan kurangnya masukan yang diberikan pada kegiatan pertanian sehingga menimbulkan resiko kegagalan atau rendahnya hasil panen yang akan diterima (Daniel, 2004:21).

Sedangkan menurut Daniel (2004:15) Hasil Produksi yaitu keluaran (output) yang diperoleh dari pengelolaan input produksi (sarana produksi atau biasa disebut masukan) dari suatu usaha tani. Hasil produksi merupakan jumlah keluaran (output) yang dapat diperoleh dari proses produksi.

Dalam usahatani pen-
erimaan merupakan hasil yang
diperoleh petani setelah selesai
proses produksi baik masih berwujud

Dalam usahatani penproses produksi baik masih berwujud 
barang-barang hasil produksi maupun uang dari hasil penjualan hasil produksi panen tersebut. Sedangkan pendapatan usahatani adalah perkalian antara produksi dengan harga jual produk (Soekartawi, 2002:54).

\section{METODE PENELITIAN}

\section{Obyek Penelitian}

Penelitian ini dilakukan di Kecamatan Selorejo Kabupaten Blitar Jawa Timur pada Anggota Simpan Pinjam Kelompok Perempuan (SPP) yang menjalankan usaha tani.

\section{Jenis Penelitian}

Penelitian ini merupakan jenis penelitian deskriptif kuntitatif. Dalam penelitian ini menganalisis perbedaan hasil produksi dan pendapatan sebelum dan sesudah menerima kredit PNPM secara kuantitatif kemudian dideskripsikan alasan adanya perbedaan.

\section{Populasi dan Teknik Penentuan}

\section{Sampel}

Populasi dari penelitian ini adalah anggota kelompok Simpan Pinjam Perempuan (SPP) yang menjalankan usaha tani yaitu berjumlah 175 anggota. Peneliti mengambil teknik pengambilan sample dilapangan secara non probability sampling dengan teknik purposive sampling.dengan pertimbangan sampel merupakan anggota SPP dengan ketentuan menjalankan usaha tani dan telah berturut-turut mengikuti progam SPP minimal 3 tahun yaitu sbesar 50 anggota.

\section{Definisi Operasional Variabel}

Adapun variabel yang diteliti dalam penelitian ini adalah:

\section{PNPM-MPd}

Adalah progam pemberdayaan dari pemerintah yang berupa pemberian kredit untuk modal usaha yang diberikan pada kelompok SPP.

2. Hasil produksi

Adalah hasil panen yang dihitung sekali panen dengan satuan kwintal (kw).

3. Pendapatan

Adalah penerimaan dari hasil usaha tani. Yaitu penerimaan kotor dihitung sekali panen dalam rupiah yang belum dikurangi dengan biayabiaya.

\section{Jenis dan Sumber Data}

Penelitianini menggunakan jenis data Primer yang bersumber dari angket atau kuisioner. Dan data 
sekunder yang diperoleh dari dokumentasi BPS dan Kantor UPK PNPM MPd di Kecamatan Selorejo Kabupaten Blitar.

\section{Teknik Pengumpulan Data}

\section{Angket (kuesioner)}

Penyebaran angket dilakukan kepada anggota SPP yang menjalankan usaha tani di Kecamatan Selorejo. Dan dengan ketentuan anggota aktif selama 3 tahun berturut-turut mengajukan kredit.

\section{Metode dokumentasi}

Metode pengumpulan data dengan cara melihat dokumentasi lembaga terkait yang diperlukan pada penelitian penelitian.Seperti data dari BPS dan laporan Pertanggung Jawaban SPP Kecamatan Selorejo.

\section{Teknik Analisis Data}

Teknik analisis data yang digunakan adalah uji beda mean untuk dua sampel berpasanganyaitu sebelum dan sesudah. Menggunakan statistik uji $t$ untuk mengetahui perbedaan hasil produksi dan pendapatan usaha tani dengan rumus: (Suryadi dan Purwanto, 2015:133)

$$
\mathrm{t}=\frac{d / n}{s d / \sqrt{n}}
$$

Dan standar devisiasi dirumuskan sebagai berikut:

$$
\mathrm{S}=\sqrt{\frac{\sum \mathrm{d}^{2}-\frac{\left(\Sigma \mathrm{d}^{2}\right)}{n}}{n-1}}
$$

dinama :

$$
\begin{array}{ll}
\mathrm{t} & : \text { Nilai distribusi t } \\
\mathrm{d} & : \text { Perbedaan antara data } \\
& \text { berpasangan } \\
\mathrm{sd} & : \text { Standart deviasi } \\
\mathrm{n} & : \text { Jumlah pengamatan } \\
& \text { berpasangan }
\end{array}
$$

Dengan prosedur :

1. Hipotesis

$\mathrm{H} 0: \mathrm{b} 1=0$ : diduga pendapatan, produksi sebelum dan sesudah mengikuti kredit PNPM MPd adalah sama.

H1 : $\mathrm{b} 1 \neq 0$ : diduga pendapatan, produksi sebelum dan sesudah mengikuti kredit PNPM MPd adalah berbeda

2. Tingkat signifikasi : $\alpha=0,05$

3. Kriteria pengujian, hasil perhitungan $\quad \mathrm{t}$ (hitung) dibandingkan pada $t$ (tabel) pada taraf signifikasi 5\%

4. Ketentuan rumus

$$
\mathrm{t}=\frac{d / n}{s d / \sqrt{n}} \quad \text { dan } \quad \mathrm{sd}=\sqrt{\frac{\Sigma \mathrm{d}^{2}-\frac{\left(\Sigma \mathrm{d}^{2}\right)}{n}}{n-1}}
$$

5. Kesimpulan

$\mathrm{H} 0$ ditolak jika (t) hitung $\geq(\mathrm{t})$ tabel. 


\section{PEMBAHASAN}

\section{Pengajuan dan Pengembalian Kredit}

a. . Mekanisme Pengajuan Kredit Berikut adalah beberapa ketentuan dan prosedur terkait dengan mekanisme pengajuan dan pemberian kredit di Kecamatan Selorejo :

Gambar 1. Alur Pengajuan kredit

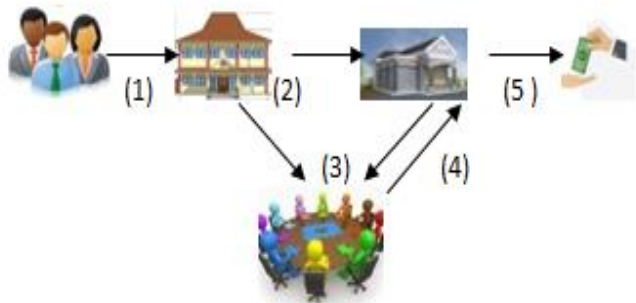

Sumber : UPK Kecamatan Selorejo

Pengajuan kredit dimulai dari pembentukan kelompok yang beranggotakan 5-20 orang yang semua berjenis kelamin perempuan.

(1) Setelah kelompok terbentuk sesuai dengan ketentuan, kelompok bisa langsung menyusun proposal pengajuan kredit dengan format dan contoh dari sekertaris UPK Kecamatan Selorejo.

(2) Setelah proposal jadi, proposal diserahkan kepada kepala desa untuk diteliti dan disetujui. Setelah disetujui kepala desa, proposal beserta lampiran foto copy KTP anggota kelompok diajukan kepada UPK SPP kecamatan Selorejo. Setelah itu diadakan verifikasi oleh UPK SPP, verifikasi sendiri dilakukan guna untuk melihat apakah kelompok bermasalah atau tidak.

(3) Ketika tahap verifikasi sudah selesai dan tidak terbukti adanya pelanggaran maka segera diadakanya musyawarah yang mengundang kepala desa masingmasing kelompok. Musyawarah ini bertujuan mencapai mufakat keputusan akhir kelompok-kelompok mana yang layak didanai dan pantas dengan dana berapa yang diberikan.

(4) Jika sudah disetujui semua pihak, UPK akan mengumumkan kelompok yang dinilai pantas didanai sesusai dengan kesepakatan bersama.

(5) Setelah itu dana bisa mulai dicairkan oleh bendahara UPK Kepada ketua masing-masing kelompok. Pencairan dana untuk tiap-tiap anggota diatur oleh ketua kelompok dengan musyawarah anggota kelompok yang terkait.

\section{b. Mekanisme Pengembalian Kredit}

Ketika tiap anggota sudah menerima kredit, maka setiap bulanya wajib untuk mengangsur 
selama satu tahun. Bunga yang ditetapkan pemerintah tergolong ringan yaitu $1,5 \%$, berikut adalah alur pengembalian kredit :

\section{Gambar 2. Alur Pengembalian Kredit}

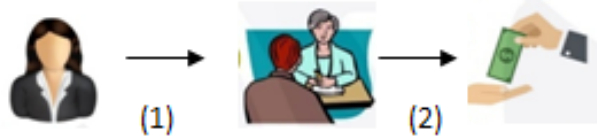

Sumber : UPK Kecamatan Selorejo

(1) Mengangsur kredit dapat dilakukan dengan mudah yaitu anggota kelompok menyetorkan agsuran kepada ketua kelompoknya.

(2) Kemudian jika angsuran dari semua anggota kelompok sudah terkumpul ketua kelompok bisamenyetorkan kepada bendahara
UPK di kantor. Jika terjadi kasus ada anggota atau kelompok yang tidak tepat waktu dalam melakukan angsuran, Maka pihak UPK akan mendatangi rumah ketua kelompok untuk meminta klarifikasi.

Ketua kelompok diminta mampu untuk mengatur dan mendisiplinkan anggota kelompoknya. Jika sampai tahun terakhir pemberian kredit, ada anggota atau kelompok tersebut belum mampu melunasi hutangnya, maka tidak bisa mengajukan kredit untuk tahun berikutnya. Dan sistem pelunasanya nanti dengan system tanggung renteng.

\section{Hasil Uji Beda Mean}

Tabel 1. Hasil Uji Beda Mean Untuk Hasil Produksi

\begin{tabular}{lllll}
\hline Variabel & Mean & $\begin{array}{l}\text { Standart } \\
\text { Devisiasi }\end{array}$ & T & Df \\
\hline $\begin{array}{l}\text { Produksi Sesudah }- \\
\text { sebelum Menerima }\end{array}$ & 1.840 & 1.444 & 9.008 & 49 \\
Kredit PNPM & & & &
\end{tabular}

Uji beda mean sample thitung) lebih besar dari t(tabel). Hal berpasangan diperoleh $\mathrm{t}$ (hitung) ini dapat ditarik kesimpulan menolak sebesar 9.008 dengan df sebesar 49 H0, Dengan begitu hipotesis pertama yang diperoleh dari $\mathrm{n}-1$, dan terpenuhi terdapat perbedaan diketahui $\mathrm{t}($ tabel) sebesar 2.00958 . signifikan produksi usaha tani SPP Dengan membandingkan $\mathrm{t}$ (hitung) dengan $\mathrm{t}($ tabel $), \quad$ bahwasanya sebelum dan sesudah menerima kredit PNPM di kecamatan Selorejo. 
Tabel 2. Hasil Uji Beda Mean Untuk Pendapatan

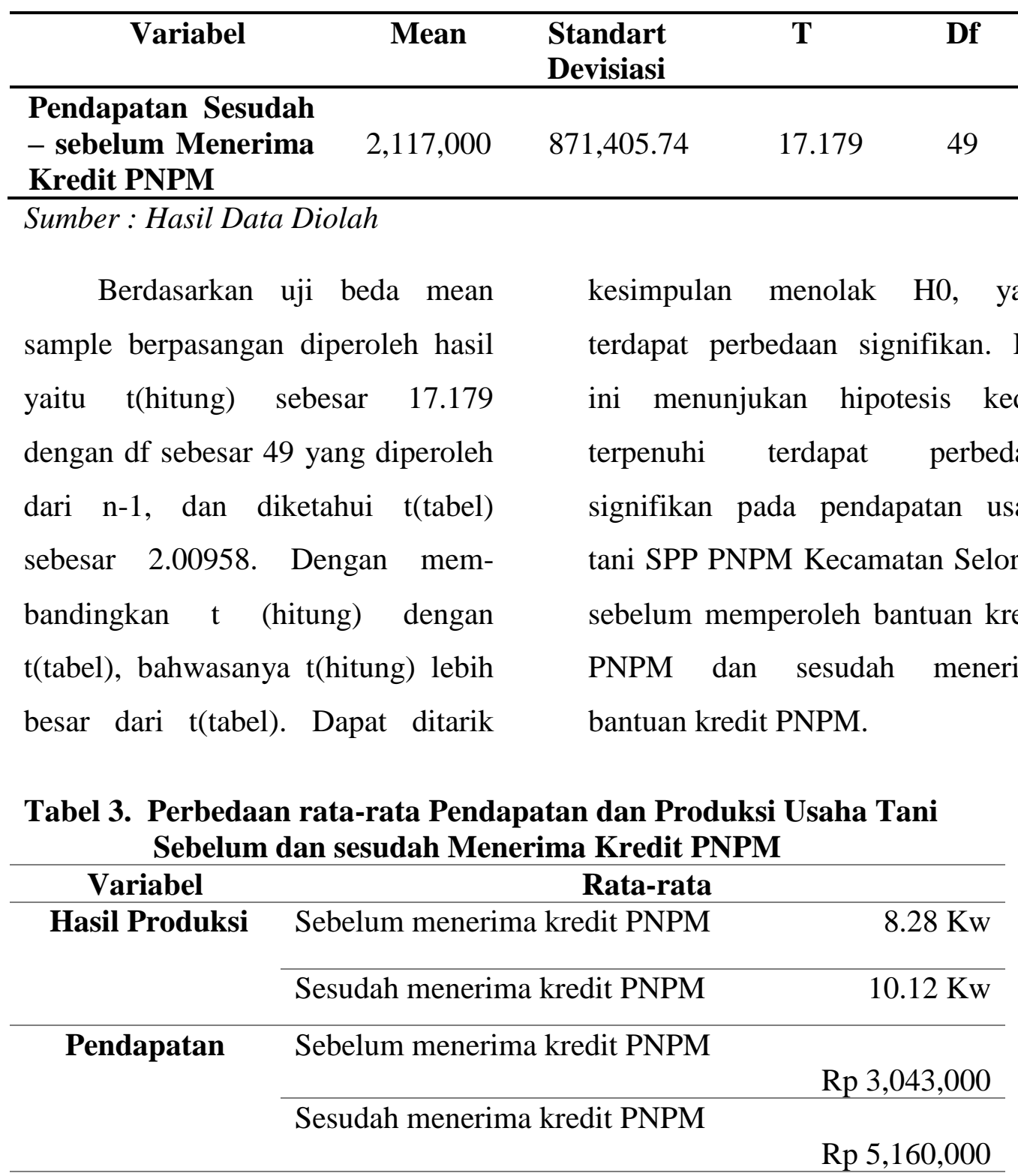

Sumber: Hasil Data Diolah

Data tersebut menjelaskan bahwa adanya peningkatan secara rata-rata pendapatan usaha tani anggota SPP sebelum dan sesudah menerima kredit PNPM yaitu sebesar Rp 2,117,000 atau 41\%. Dan pada produksi usaha tani anggota SPP sebelum dan sesudah menerima kredit PNPM yaitu sebesar $1.84 \mathrm{kw}$ atau $18.2 \%$. hal ini menunjukan kredit PNPM mampu meningkatkan produksi dan pendapatan usaha tani anggota SPP kecamatan selorejo. 
3. Deskripsi Adanya Perbedaan a. Hasil Produksi

Perbedaan atau peningkatan pada hasil produksi usaha tani, tentu memiliki alasan hal apa saja yang melatar belakangi adanya peningkatan. Menurut responden hal yang membuat panen mereka meningkat adalah dijelaskan oleh tabel di bawah ini:

Tabel 4. Penyebab Hasil Produksi Mengalami Peningkatan

\begin{tabular}{lll} 
Hal yang di lakukan & $\begin{array}{l}\text { Jumlah } \\
\text { (Orang) }\end{array}$ & Prosentase (\%) \\
\hline
\end{tabular}

a) Melakukan perawatan : seperti pemupukan, penyemprotan pestisida dan 40 80 menghilangkan rumput

b) Menambah lahan untuk menambah tanaman lagi 5 10

c) Memilih bibit yang unggul 5 10

\section{Sumber : Hasil Data Primer}

Peningkatan tersebut dapat terjadi karena ada suatu hal penyebab yang melatar belakanginya. $80 \%$ atau 40 orang responden menyatakan yang membuat hasil produksi taninya meningkat adalah dengan memberi perawatan seperti pemupukan, penyemprotan hama dan menghilangkan rumput. Sedangkan 10\% atau 5 orang responden menyatakan yang membuat hasil produksi taninya meningkat adalah menambah lahan untuk menambah tanaman. Dan 10\% atau 5 orang lainya menyatakan melakukan pemilihan bibit yang unggul.
Dari 40 orang responden yang menyatakan panen mereka meningkat karena melakukan perawatan memiliki beberapa alasan, yaitu: sebanyak 25 orang menyatakan karena dengan melakukan perawatan tanaman, tanaman dapat tumbuh dan berkembang dengan baik. Dan sebanyak 15 orang responden menyatakan sudah tidak memiliki lahan lagi untuk menambah tanaman. Sehingga hal yang bisa mereka lakukan dan dirasa efektif untuk meningkatkan hasil panen adalah melakukan perawatan seperti pemupukan, penyemprotan hama dan menghilangkan rumput. 
Sedangkan 5 orang responden yang menyatakan panen mereka meningkat karena melakukan penambah lahan untuk penambah tanaman memiliki alasan, yaitu: sebanyak 3 orang menyatakan bahwa mereka masih memiliki lahan yang belum sempat ditanami. Dan Sebanyak 2 orang menyatakan bahwa jika tidak melakukan pertambahan tanaman dan perluasan lahan tanam peningkatan hasil panen pun dirasa kurang maksimal.

Sisanya sebanyak 5 orang responden lainya menyatakan panen mereka meningkat karena memilih bibit yang unggul dengan alasan yaitu : sebanyak 1 orang menyatakan karena bibit unggul menentukan hasil panenan. 3 orang menyatakan memilih bibit yang unggul dapat menghasilkan hasil buah yang banyak. Dan sebanyak 1 orang menyatakan karena bibit unggul memiliki tingkat bertahan hidup lebih tinggi dibandingkan dengan bibit biasa sehingga jika tanaman banyak yang tumbuh maka panen pun semakin banyak.

Didapatkan $80 \%$ hal yang meningkatkan hasil produksi panen anggota SPP Kecamatan Selorejo adalah dengan perawatan tanaman seperti pemupukan, penyemprotan pestisida dan menghilangkan rumput. Hal tersebut berbanding lurus dengan penggunaan dana kredit PNPM-MPd oleh responden yaitu $80 \%$ untuk membeli pupuk dan obat pestisida. Dengan demikian, dengan adanya kredit PNPM-MPd dapat membantu petani untuk meningkatkan hasil produksi panen.

\section{a. Pendapatan}

Perbedaan dalam arti peningkatan dipenelitian ini pada pendapatan usaha tani, tentu memiliki alasan hal apa saja yang melatar belakangi adanya peningkatan. Berikut akan dijelaskan oleh tabel dibawah ini: 
Tabel 5. Penyebab Pendapatan Meningkat

\begin{tabular}{|c|c|c|c|}
\hline & $\begin{array}{c}\text { Hal yang membuat pendapatan } \\
\text { meningkat }\end{array}$ & $\begin{array}{l}\text { Jumlah } \\
\text { (orang) }\end{array}$ & $\begin{array}{c}\text { Prosentase } \\
(\%)\end{array}$ \\
\hline a) & $\begin{array}{l}\text { Karena hasil panen yang meningkat } \\
\text { dari segi bobot (kuantitas) dan segi } \\
\text { kualitas (mutu). Dan karena harga } \\
\text { belikomoditi tanaman yang ditanam } \\
\text { mengalami peningkatan. }\end{array}$ & 44 & 88 \\
\hline b) & $\begin{array}{l}\text { Karena hasil panen yang meningkat } \\
\text { dari segi bobot (kuantitas) dan segi } \\
\text { kualitas (mutu). }\end{array}$ & 6 & 12 \\
\hline
\end{tabular}

\begin{abstract}
Berdasarkan tabel 5 dapat diketahui hal yang membuat pendapatan usaha tani anggota SPP meningkat adalah 44 orang menyatakan bahwa karena hasil panen mereka mengalami peningkatan dan harga beli hasil panen juga mengalami peningkatan. Dan 6 lainya mengatakan karena hasil panen mereka yang meningkat.
\end{abstract}

Sebesar 44 orang menyatakan bahwa pendapatan mereka meningkat karena hasil panen dan harga beli komoditi yang mereka tanam mengalami peningktaan. Dengan alasan mereka mengalami kedua hal tersebut yaitu memiliki hasil panen yang meningkat dan harga yang diberi dari tengkulak pun mengalami peningkatan. Sedangkan alasan, 6 orang yang menyatakan pendapatan mereka meningkat disebabkan oleh hasil panen adalah karena hasil panen mereka selalu mengalami peningkatan. Namun harga beli komoditi tanam mereka hanya mengalami sedikit peningkatan harga.

\section{b. Perbandingan Hasil Produksi dan Kenaikan Harga dalam \\ Peningkatan Pendapatan}

Secara lebih rinci hal yang membuat pendapatan tani mengalami peningkatan lebih disebabkan oleh hasil produksi atau kenaikan harga dapat dijelaskan dengan perbandingan antara rata-rata hasil produksi dan rata-rata peningkatan harga oleh tabel berikut :

Tabel 6. Perbandingan Hasil Produksi dan Harga

\begin{tabular}{lcccc}
\hline Perbandingan & Sebelum & Sesudah & Selisih & Prosentase \\
\hline Hasil produksi & Kw 8.28 & Kw 10.12 & Kw 1.84 & $18 \%$ \\
\hline
\end{tabular}




\begin{tabular}{lllll}
\hline Harga & Rp 6,206 & Rp 7,974 & Rp 1,768 & $23 \%$ \\
\hline
\end{tabular}

Sumber: Hasil Data Diolah

Secara lebih rinci, peningkatan pendapatan lebih ditunjang dari kenaikan harga dari pada hasil produksi. oleh Diketahui bahwa 18\% peningkatan pendapatan disebabkan oleh hasil produksi dan sebesar $23 \%$ kenaikan pendapatan disebabkan oleh kenaikan harga. Hal tersebut dapat disimpulkan bahwa penyebab peningkatan pendapatan usaha tani di kecamatan Selorejo paling banyak disebabkan oleh kenaikan harga dari pada hasil produksi. Kenaikan harga sendiri disebabkan oleh pasar yang memang harga komoditi tanam tersebut mengalami kenaikan dan juga ditunjang dari kwalitas hasil produksi itu sendiri. Semakin hasil produksi panen berkwalitas entah itu dari sedi bentuk, rasa, aroma dan lainya baik menurut tengkulak atau pasar maka akan meningkatkan harga, selain dari segi bobotnya.

Dengan demikian kredit PNPM-MPd mampu meningkatkan hasil produksi usaha tani secara bobot dan kwalitas yang akan meningkatkan pendapatan usaha tani anggota SPP di Kecamatan Selorejo Kabupaten Blitar.

\section{PENUTUP}

\section{Kesimpulan}

Berdasarkan hasil penelitian dapat ditarik kesimpulan bahwa adanya perbedaan hasil produksi usaha tani sebelum dan sesudah menerima kredit PNPM-MPd. Dengan Uji t(hitung) menunjukan nilai 9.008 yaitu lebih besar dari $\mathrm{t}$ (tabel) 2.00958. Perbedaan juga terlihat pada rata-rata hasil produksi usaha tani sebelum menerima kredit sebesar 8.28 Kw dan setelah menerima kredit menghasilkan 10.12 Kw. Hal ini menunjukan adanya perbedaan yaitu hasil produksi meningkat sebesar $1.84 \mathrm{Kw}$ atau 18 $\%$.

Adanya perbedaan pada pendapatan usaha tani sebelum dan sesudah menerima kredit PNPMMPd. Dengan Uji t(hitung) menunjukan nilai 17.179 yaitu lebih besar dari $t$ (tabel) 2.00958 . Perbedaan juga terlihat pada rata-rata pendapatan usaha tani sebelum menerima kredit sebesar Rp 3,043,000 dan setelah menerima kredit sebesar Rp 5.160.000. Hal ini menunjukan bahwa adanya 
peningkatan pendapatan sebesar $\mathrm{Rp}$ $2,117,000$ atau $41 \%$.

Perbedaan atau peningkatan terbesar terjadi pada pendapatan usaha tani walaupun hasil produksi yang didapatkan memiliki perbedaan atau peningkatan yang kecil. Perbedaan atau peningkatan pada pendapatan usaha tani juga ditunjang dari kenaikan harga komoditi tanam. Peningkatan pendapatan disebabkan sebesar $18 \%$ oleh hasil produksi dan $23 \%$ oleh kenaikan harga.

\section{Saran}

1. Bagi Pemerintah

Untuk meningkatkan hasil produksi usah tani hendaknya pemerintah disamping memberikan bantuan kredit permodalan juga memberikan pelatihan kepada petani. Pelatihan tersebut ditujukan untuk petani agar dapat memanfaatkan lahan yang ada untuk meningkatkan hasil produksi mereka.

\section{Bagi Peneliti Selanjutnya}

Beberapa saran untuk peneliti selanjutnya untuk mengembangkan penelitian ini antara lain :

1) Diharapkan peneliti tidak hanya menganalisis dari segi ekonomi saja, peneliti bisa menambahkan analisis dari segisosial ekonomi .

2) Jika peneliti ini hanya menganalisis pendapatan dan produksi usaha tani pada satu populasi, hendaknya peneliti selanjutnya mampu membandingkan dengan populasi lain atau dengan kecamatan lain.

3) Peneliti selanjutnya dapat menambahkan sampel agar lebih mewakili populasi.

\section{DAFTAR PUSTAKA}

Anwas, M. 2013. Pemberdayaan Masyarakat di Era Global. Badung : Alfabeta.

Badan Pusat Statistik Kecamatan Selorejo. Kecamatan Selorejo Dalam Angka 2016. https://blitarkab.bps.go.id/inde x.php/publikasi/362. ( diakses pada 2 februari 2017).

BAPPENAS. Evaluasi PNPM Mandiri 2013.

http://www.bappenas.go.id/file s/ekps/2013/3.Evaluasi\%20PN PM\%20Ma ndiri.pdf (diakses pada 19 November 2016).

Daniel, Moehar. 2004. Pengantar Ekonomi Pertanian. Jakarta :PT Bumi Aksara.

Ishom, Faizul. 2015. Arah Kebijakan Tata Kelola Pasca Pengalihan PNPM Mandiri. Jakarta : KementrianDesa Pembangunan 
Daerah Tertinggal dan Transmigrasi Republik Indonesia.

https://www.kemenkopmk.go.i d. (diakses pada 2 Januari 2017).

Lestari, Purwanti. 2013. “ Pengaruh Kredit SPP (Simpan Pinjam Kelompok Perempuan) PNPMMP Terhadap Masyarakat “. Vol,01.No,01.Semarang:

Pendidikan Ekonomi IKIP Veteran.https://www.digilib.iki p.veteran

Media Informasi Warga Selorejo. 2016. "Belajar Dari Selorejo". www.ojeroles.com. (diakses pada 7 November 2016)

Nurmanto, Bogi. 2011.”Analisis Ekonomi Progam Nasional Pemberdayaan Masyarakat Mandiri Perdesaan (PNPMMPd) di Kecamatan Ngargoyoso Kabupaten Karanganyar".Skripsi.Surakart a: Fakultas Ekonomi dan Bisnis Universitas Sebelas Maret.https://digilib.uns.ac.id (di akses pada 20 November 2016).
Soekartawi.2002. Prinsip Dasar Ekonomi Pertanian.,Jakarta : Raja Grafindo.

Suhardjono, 2003. Manajemen Pengkreditan : Usaha Kecil dan Menengah. Yogyakarta : AMP YKPN.

Suharyadi dan Purwanto. 2015. Statistika Untuk Ekonomi dan Keuangan Modern. Jakarta : Salemba Empat.

Sulistiyani, A.T. 2004. Kemitraan dan Model-ModelPemberdayaan. Yogyakarta: Gaya Media.

Tim PNPM. 2007. Buku Petunjuk Teknis Operasional Progam Nasinal Pemberdayaan Masyarakat (PNPM Mandiri Persesaan), Republik Indonesia

UPK Kecamatan Selorejo. 2016. Laporan Pertanggung Jawaban Kegiatan Simpan Pinjam Kelompok Perempuan Kecamatan Selorejo 2016. Kecamatan Selorejo. 